\title{
8. Peace journalism: A paradigm shift in traditional media approach
}

\section{ABSIRACI}

Power, politics and profit have been the key factors in determining the media's traditional approach towards conflict. But in recent decades, the debate on 'peace journalism' as an approach to conflict has gained momentum and several scholars (Galtung, 1973; Lynch, 2005; Bell, 1998; Howard, 2003; Allan, 2007; Keeble, 2010) have argued in favour of the concept. However, many questions pertaining to the extent of effectiveness of peace journalism and its application to other forms of media remain unanswered. This article is an attempt to explore answers to these questions. It argues that there is a beginning of a paradigm shift in the traditional media's approach to conflict situations. While peace journalism was been linked with conflict resolution and advocacy, there is now greater acceptance of it as an attitude that frames a news story. There are also examples to show that it is being applied to other media such as photojournalism, documentary making, film production, investigative journalism, community and specialised media. At the same time, advocates and practitioners of peace journalism face several challenges as there is no universal standard to deal with conflicts.

Keywords: peace journalism, conflict reporting, conflict resolution, war correspondence

\section{RUKHSANA ASLAM}

Pacific Media Centre, AUT University

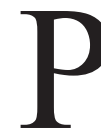

EACE JOURNALISM is not a new concept. It originated in the 1970s when John Galtung (1973) drew parallels and contrasts between towards violence by virtue of focusing on the events taking place in a conflict and their physical details like the number of people dying or the nature of weaponry used. It does not analyse the processes that lead to the conflict including its causes, outcomes and impact on human lives. Also, war 
journalism tends to view the conflicts in terms of defeat or victory for the either side. On the other hand, peace journalism offers an alternative approach to journalists (Galtung, 1998). While giving the physical account of the conflict, they ought also to give the structural and cultural causes of violence as they affect the lives of the people. Such news stories aim to provide a platform for communication between all the conflicting parties and, at the same time, suggest possible solutions or initiatives that can reduce the intensity of the conflict.

One fundamental difference between the two kinds of journalism reporting conflict is that the reporters in the former are expected to be 'dispassionate observers' of the events whereas peace journalists assume a more 'involved role' giving opinions along with the facts.

Several scholars have worked in this arena and developed the notions of peace journalism as a means to provide a more meaningful role for journalists covering conflicts and such studies are gaining momentum (Lynch, 2005; Bell, 1998; Howard, 2003; Allan, 2007; Keeble, 2010). Two developments in the mainstream media point towards changing attitudes and the promise of a paradigm shift in journalistic trends and practices.

First, there is a consensus building among journalists, media professionals, audiences and conflict resolution experts that there is 'something seriously wrong' with contemporary media coverage of war and conflicts. Freelance journalists like Jon Stephenson, who covered the Afghan War, attribute it to the "tight deadlines and constant battle for a spot on TV which discourages the journalists to do any worthwhile in-depth reporting. While others, such as Fiji academic Mosese Waqa (2010), think the mainstream media has been rejecting peace journalism for a decade simply because conflict sells.

...for one thing, the rhetorical and narrative structures that shape and constrain the way in which conflicts have been reported have been largely due to persistence by the common practice that reporting 'naked violence' in conflict sells news and is good for business and raising ones profile ... while good quality storytelling that invites honest introspection in peeling the layers of interconnected complexities of a conflict situation (like the 'cycle' of coups in Fiji) and suggesting alternatives on how better futures can come to fruition in the lives of people affected, their communities and country has never really been given the chance to find its rightful place in social discourses. (Waqa, 2010) 
The second important development is that the 'call for peace journalism' is coming from practising journalists and media professionals who have personally witnessed conflict situations and have found the traditional media approach lacking, both in terms of bringing a better understanding to the people about conflicts through comprehensive stories and in creating impact on the key players to want to do something about it.

The power of the media to have this kind of impact is often talked about when recalling the famous picture seen worldwide of the little Vietnamese child seen running down on the road after being caught in the blue flames of napalm gas. This picture tilted public opinion against the American war. At that time live coverage of wars was not possible, conflicts had not entered our drawing rooms and the newspapers had longer shelf-life. The television news was not plagued by live reporting or constant half-hourly updates and the information super-highway was still a dream. In short, the news media back then did not have that temporal quality that is its hallmark today. Editions of newspapers, magazines and journals actually looked like the 'first drafts of history' as they gave enough time and space to war correspondents to do their investigations in their own time and come out with comprehensive articles. Today, media demands and constraints would allow few people to rise to the stature of James Cameron, for example.

These two developments indicate the beginnings of a paradigm shift in the traditional media's approach to conflict situations. Currently the media operates on the principles governed by the triangle of power, politics and profit. But as the call for 'peace journalism' gets stronger, the triangle is turning into a quadrilateral with peace as its fourth corner. The new paradigm offers the same kind of flexibility to the media that a triangle does but also provides additional space for peace journalism which can make the news stories more meaningful. While peace journalism was always linked with conflict resolution and advocacy, there is now greater acceptance of it as an attitude that frames a news story. It is being applied to other disciplines and forms of media such as photojournalism, documentary making, film production, investigative journalism, community and specialised media, democracy and even good governance.

While media reflects the evolution of society, it also absorbs these changes within itself. Hence it is important that journalists engage in self reflection and critically re-evaluate the values and practices in their profession. This is the key to any change in attitude and approach towards journalism. This article 
traces the beginnings of a paradigm shift in the traditional media's approach to conflict situations and examines the themes of a peace journalism seminar at the Media, Investigative Journalism and Technology (MIJT10) conference in Auckland last December.

\section{How does peace journalism apply to other forms of media?}

What is the difference between peace journalism and 'good journalism'? Much of this debate can be found in the journal Conflict and Communication Online (2007). While Lynch (2007) propagates the merits of peace journalism, his opponents like Loyn (2007) argue that it is basically just 'good journalism'. If journalistic standards are good then why should they be labeled as peace, they argue, which is quite true except that this is precisely the problem: contemporary journalism standards are widely regarded as poor, conflicts are being sold and the victims manipulated to bring in profits.

On the other hand, scholars like Loyn (2007) are probably right to mistrust the word 'peace'. As Devere and Verbitsky (2010) argue, there is something about the word that evokes different responses from different people including 'unease' especially among those in power. How frequently in history are terrible crimes and injustices done to the humanity in the name of bringing 'peace', they ask.

But true or not, there is little denying that the concept of peace journalism has value and appeal for the reporters and audiences. Koroi Hawkins (2010), a television journalist from the Solomon Islands, said at the Auckland peace journalism forum: 'We as journalists did not know how to handle the conflict in our region. If we were trained in peace journalism we would have reported better and perhaps helped saved many lives.' Shailendra Singh (2010), a former news magazine editor and now media educator from Fiji, recalled at the forum that: 'It was after going through conflict situations that we have realised the importance of peace journalism and now efforts are being made to sensitise and train journalists in Fiji, although finding resources and expertise is always a problem.'

\section{Defining the right kind of journalism}

The media have a role to play in conflict situations. The nature of that roleas a perpetrator of a conflict or agent for peace-largely depends on the framing and agenda-setting of the media. Researchers have also established that the biases and prejudices of journalists at the individual level can be 
reflected in the interpretation of the events (Entman ,1993; Brosius, 1996). This realisation has extended the debate from 'what is' to 'what should be' regarding the role of media in conflict situations and new concepts have emerged such as 'civic journalism', 'caring journalism', 'peace journalism', 'citizen journalism', 'reliable journalism' and 'innovative journalism'. All of them are essentially drawn from notions which stress the social responsibility of the media and advocate a proactive role for the media in resolving conflicts.

Lynch (2008 p. 38), a freelance British television reporter and academic, is one of the chief proponents of what he calls the 'peace journalism option'. He believes that mainstream coverage of conflicts concentrates on highlighting events and generally represents war as a simple 'them versus us' struggle in which one side wins and the other loses. Martin Bell (1998), a former BBC correspondent and later independent MP, seriously questioned the Western coverage of Bosnian ethnic cleansing in 1994-95. He called for a journalism of attachment 'that cares as well as knows ... that will not stand neutrally between good and evil, right and wrong, the victim and the oppressor' (p. 16). The BBC's guidelines required reporters to be objective and dispassionate. Bell continued:

I am no longer sure what 'objective' means: I see nothing object-like in the relationship between the reporter and the event, but rather a human and dynamic interaction between them. As for 'dispassionate', it is not only impossible but inappropriate to be thus neutralised-I would say even neutered at the scene of an atrocity or massacre, or most man-made calamities. (Bell, 1998, p. 18)

In a similar vein, Ross Howard (2003) points out the need for a more reliable journalism.

Reliable journalism means journalism practices which meet the international standards of accuracy, impartiality and social responsibility. There is also support for creating diversity within the media industry to reflect competing opinions and to ensure the industry enjoys independence. (Howard, 2003)

Howard also mentions another kind of initiative called 'intended outcome programming' which sees entertainment, street theatre, dramas and posters 
as the means to communicate attitudes towards conflict resolution. This initiative is seen mostly in the developing countries where the literacy rate is low.

The media becomes a facilitator of positive social change rather than a professional disinterested observer. This kind of initiative...is not journalism as we know it, although it adheres to values such as accuracy, fairness and responsibility. It is attractive to both audiences and donors. (Howard, 2003)

Stuart Allan (2007) sees the rise of 'citizen journalism and mass-self communication' (through email, blogs, vlogs, SMS and now Twitter) as a direct alternative to 'journalism's traditional role or mission, its public responsibilities'. He quotes Lewis D'Vorkin, editor in chief of AOL News: 'The world is turning to the fastest growing news team-citizen journalists - to get a human perspective through the eyes of those who lived or experienced the news as it unfolds.'

Here is the bottom line: whatever name one chooses to give to journalism, it reflects one's approach to the events and situations around oneself. Furthermore, while the debate revolves around the media, all these suggested solutions focus too much on 'journalism' and not enough on the journalist as an individual. At the time of reporting it is journalist-the-individual whose words are being read or heard, whose images are being seen and whose interpretation of the events forms the 'first draft of history'. In this moment, the political economy of the media system is pushed into the background. In short, a journalist's attitude or approach towards the conflict will decide the framing of the story regardless of the format that is chosen to do so. For instance, in visual media like film and documentary, it is the vision of the director that determines its tone and message. Schubart (2010, p. 4) has talked about how war has become a theme for entertainment in the visual media including games, sitcoms, TV serials and movies. The children's media in particular has been used for learning, entertaining and educating, e.g. the world famous Sesame Street. Similarly minority and gender issues have been dealt with in special programmes and films like Roots. Hence as an approach, peace journalism is not restricted to news media. It can be equally meaningful when applied to other forms of mass media like documentary making, photojournalism, entertainment media, media for children and specialised media like those for women and minorities. 
This indicates a paradigm shift in the traditional media's approach to conflict from triangle to a quadrilateral. Peace journalism was always linked with conflict resolution but now it is also increasingly being applied to photojournalism, documentary making, film production, investigative journalism and community programmes. Most recently, Kunda Dixit brought his photographic exhibition Frames of War to Auckland which was a pictorial story of the Maoist war in Nepal and was one of the highlights of the MIJT conference. Dixit worked as a 'parachute' journalist for the BBC before civil war broke out in Nepal in 1996. His confession was that war correspondents, including him, 'behaved like soldiers'; they went to a bar at the end of the day and spoke in military jargon (Dixit, 2011). However, when returning to war-torn Nepal, it was no longer 'someone else's war':

It was my war and it was my people who were dying. Journalism schools teach us not to get too involved; to be a spectator. But back home I could not... We had to look beyond the battles ... We had to look at the human cost. (Dixit, p. 11)

Being a mainstream journalist, he soon realised that 'the problem in war reporting in Nepal was that journalists were not involved enough; that there was no space for in-depth stories'. So Dixit and his two friends decided to turn to other means. 'I chose photojournalism to tell the Nepal story through pictures while one of my friends wrote a novel and the other has made a documentary,' he said. Finding alternative media was not only another way for them to put across their message for peace, it also became their salvation.

On the one hand, Dixit and his friends' experience support what is argued in Peace Journalism, War and Conflict Resolution (Keeble et al., 2010).

Journalists need to be aware of their own weaknesses and biases. They are a product of society and hence not free from their own biases and misperceptions which are ingrained in their minds from childhood. These biases might not be prominent in conflicts where they can act as "outside observers" but when faced in conflicts which challenge their own ideologies and beliefs as individuals or citizens these biases are reflected in their language and approach to the issue.(Aslam, 2010, p. 344)

On the other hand, it demonstrates how the new paradigm of peace journalism can offer new opportunities to journalists to tell stories in different ways without losing their value or appeal for the audience. 
Believers in peace journalism are not the only ones asking for such a 'mind-shift' in practising journalism. New Zealand journalist and author of four books on investigative journalism, Nicky Hager (2010), talked about the need to redefine investigative journalism in his speech at the MIJT conference. Acknowledging that the days of uncovering a Watergate-type story within a traditional newspaper were over, he said there was a need to 're-conceptualise what we think investigative journalism is and who we think an investigative journalist is'.

He also presented a new model to breathe fresh air into this fast-declining form of journalism. It includes finding independent funding sources and grants, 'search[ing] out the people who call themselves filmmakers or public interest researchers for example and bring[ing] those people together'. When combined with 'the best parts of traditional journalism: accuracy, fairness and balance, as well as editorial checking and protection of sources, it would be possible to safeguard against any decline,' he said.

At the same conference, Renee Barnes, a lecturer from RMIT Australia, talked about the possibilities of 'realigning Twitter for alternative journalism education'. Professor Wendy Bacon, director of the Australian Centre for Independent Journalism (University of Technology, Sydney), said journalism was at the cusp of change: 'Journalism is becoming an interactive process across space and time and we can develop this to a larger, more comprehensive project.'

The conflict resolution experts have developed their own links. Dr Verbitsky, senior lecturer at Auckland University of Technology (AUT) and a specialist in conflict resolution, has drawn the links between conflict resolution and peace journalism:

There are several links between the two. Journalists act like mediators when they bring together the conflicting parties and help them talk to each other. They might not resolve the conflicts per se, but they do provide a basis for communication which is essential to resolving conflicts and offer possible solutions. But in order to be effective, they must analyse and evaluate the conflict situation keeping in view its social environment and cultural context.

Dr Heather Devere, director of practice at Otagu University's National Centre for Conflict and Peace Studies, says peace journalism and conflict resolution were essentially intertwined: 'In fact, I think that our students 
would benefit as much from studying peace journalism and how media can interpret conflicts and shape public perception of conflicts as it would be for the students of journalism to study conflict resolution and analysis.' This is an echo of what Howard (2003) has argued in the past:

As a profession, journalists are in constant search of conflict as news, and they have rudimentary to highly sophisticated skills in reporting it in conventional terms. But world-wide, journalism training and development contains almost no reference to the discipline of conflict analysis. Little of the wisdom of nearly five decades of academic and professional study of conflict is included in journalism training, and certainly not at the basic level. This is unfortunate because such knowledge can better inform journalists in their work, especially in their analysis of conflict, its sources and its alternative responses and in their reporting of efforts to diffuse conflict. (Howard, 2003)

As can be seen, there is already a paradigm shift in the traditional definition of journalism as well as in its application to other forms of media. What remains is the gradual strengthening of this new paradigm so that it is sustainable.

\section{Can the ideals of peace journalism be transformed into practice?}

In the journalistic context, much of peace journalism is the combination of an individual's approach to a conflict situation and plain good contextual journalism (Robie, 2010). Providing that the media has the potential to educate, inform, correct misperceptions, enable consensus-building, build confidence and offer plausible solutions, the question should be asked: Can the ideals of peace journalism be transformed into practice?

There are two aspects to this kind of journalistic education: theoretical knowledge and practical exposure. The first can give the contextual and conceptual understanding of what constitutes conflict, peace and violence while the second can provide the skills and tools required to report on conflict situations.

\section{Journalistic training in the field: Trends and practices}

Journalistic training in the field is meant for journalists already working in the profession. It may be conducted by non-profit organisations, media organisations or by a self-motivated group of media workers and aims for skills enhancement and capacity-building of journalists in the form of training workshops and seminars.There are several examples of such projects 
around the world which target various aspects of journalistic training in conflict resolution ranging from developing reporting skills in the conflict areas to employing safety and survival techniques and post-conflict trauma awareness programmes.

One example of an organisation promoting research and guidance for journalists in conflict situations is the Network of Conflict Resolution in Canada (www.nicr.ca). One of the tools it offers is the Alternative $5 \mathrm{Ws}$ for conflict reporting:

Who: Who is affected by this conflict? Who has a distinct stake in its outcome? What is their relationship to one another, including relative power, influence and affluence?

What: What triggered the dispute? What drew it to your attention at this time? What issues do the parties need to resolve?

When: When did this conflict begin? How often have the circumstances existed that gave rise to this dispute?

Where: What geographical or political jurisdictions are affected by the dispute? How has this issue been handled in other places?

Why: Why do the involved parties hold the positions they do? What needs, interests, fears and concerns need to be addressed?

How: How are they going to resolve this? By negotiation, mediation, arbitration, administrative hearing, court, armed warfare? What are the costs/benefits of the chosen method?

Options: What options have the parties explored? How do the various options relate to the interests identified?

Another such organisation is the non-profit Medios Para La Paz (Media for Peace) (www.mediosparalapaz.org) which was created in Colombia in 1997 by a group of journalists who wanted to find a way to contribute to peacebuilding. Since then, Medios Para La Paz has delivered workshops, roundtables, publications and created a network of journalists. They promote the 'disarmament of language' used by journalists so that words may become instruments of understanding and reconciliation. A dictionary entitled Para desarmar la palabra (Disarming words) was published in 1999, followed by Traps of war journalism and conflict in July 2001 which records the peace process negotiations in Colombia since the 19th century. It analyses the current peace efforts and recommends actions for an approach to 
journalism which can serve the current peace process. So far, Medios Para La Paz has offered 37 workshops to 990 journalists from around Colombia. Topics covered include conflict resolution, Colombian and international law, humanitarian law and journalistic efforts to contribute to peace.

Another effort in professional journalistic training is the Crimes of War Project which was set up following the publication of The crimes of war: What the public should know, in 1999 by Roy Guttman, the Pulitzer Prize-winning journalist who exposed the Serbian concentration camps during the Bosnian war (1992-5). The project is collaboration between journalists, lawyers and scholars dedicated to raising public awareness of the laws of war and their application to situations of conflict among journalists, policy makers and the general public. Through its website www.crimesofwar.org, educational programmes and seminars, the project also hopes to promote consultation among journalists, legal experts and humanitarian agencies about how to increase compliance with international humanitarian law.

The Asia-Pacific Institute for Broadcasting Development (AIBD) has initiated a number of projects to train journalists in conflict resolution. They have conducted a number of workshops in Nepal, Sri Lanka, Pakistan India, Philippines, Bangladesh and Indonesia. Its latest project is a joint television project by two producers, one from Pakistan and one from India, on the children of Kashmir entitled 'Children growing up in a conflict situation'. Broadcasting such joint programmes, the institute hopes to reduce the tensions between the two countries by highlighting the stories of children through entertainment (see Mottaghi, 2008).

The UK-based Dart Centre Europe is a global network (www. dartcenter. org/europe) of journalists and mental health professionals. It helps journalists cope with post-conflict trauma. It works with the BBC, ABC Australia, the Washington Post, Al Jazeera, NBC, WDR in Germany and other international news organisations as well as some major journalism schools in the US and UK.

The International Institute for Journalism (IIJ) at InWENT-Capacity Building International, Germany (www.inwent.org/iij/index.php.en), has been offering advanced training courses for mid-career journalists from developing and transitional countries since 1964 with special focus on print and on-line media in Sub-Saharan, Africa, Asia and the Middle East. The emphasis is placed on political reporting, economic and financial reporting, on-line journalism and media ethics in the light of conflict transformation and peace building. 


\section{Starting from the classroom}

The argument remains whether journalism training in conflict resolution should be conducted in the classrooms or left to be learned in the field. The first choice might reap more benefits for various reasons. First, the curricula in most universities in the developed world that offer degrees in journalism are already designed to provide the skills required in the field: reporting, editing, news gathering, publishing, production, broadcasting and even specialised reporting. Making such subjects as conflict analysis and resolution part of their scheme of studies can more easily develop the students' sense of social responsibility and also help prepare them to face challenges in the field.

Secondly, it would help initiate more research on the impact of peace initiatives on people's lives. At present, universities offering degrees in mass communication or communication studies focus more on the theoretical subjects such as media and society, social change, communication theories, and development support communication but little in the area of conflict resolution. However, in recent years some universities have launched peace and conflict studies. More research into the actual and potential role of media in conflict resolution is desperately needed. Howard (2003) argues that despite the media playing significant roles in conflict situations, the effect of media interventions on peace processes is not well documented. And as Adam and Holguin (2003) point out:

Bearing in mind the proliferation of local and regional conflicts since the end of the Cold War, along with the emergence of new communications technologies, the interaction of media and conflict is likely to be a growth activity. What is needed is an academic institution to monitor this field and publish action research. There also needs to be much more research into an evaluation methodology which can help determine the media's impact in the peace-building process. This would need to be an innovative, participatory methodology that could be used by production teams as well as specialist evaluators.

Thirdly, journalists need to be aware of their own weaknesses and biases. Those who are able to develop sensitivity towards conflict situations do so after years of working in actual conflict situations and have started questioning the role of media in it. The sensitivity towards social conflicts and situations along with the knowledge about concepts such as resolution 
and prevention need to be developed among journalism students within the classroom along with other journalistic values.

And finally it is in classrooms that the basic journalistic professional values and practices are ingrained in the students. What makes the news? Who makes the news? Most of the text books on journalism would answer 'conflict' to the first question and 'important people' to the second. Can such an approach, which judges the value of a news item in terms of the numbers of deaths or the position of a person speaking, make room for the slow process of peace building or be a voice of the people at grass root level against the high profile politicians or officials? John Paul Lederach (1997), as noted peace researcher, says that mainstream media tends to marginalise "people at grassroot from the conflict simply by giving more emphasis to the "official sources":'

I have not experienced any situation of conflict... where there have not been people who had a vision for peace, emerging often from their own experience of pain. Far too often, however, these same people are overlooked and disempowered either because they do not represent 'official' power, whether on the side of government or the various militias, or because they are written off as biased and too personally affected by the conflict. (Lederach, p. 94)

Professor Bacon (2010) says there is a "need to start seeing the role of a university in journalism beyond the "training" or "early career" models'. She argues this shift in attitude is important because otherwise it is 'a real impediment to what the possibilities are for us'. And the advantages of journalism produced in a university include fact-checking exercises with high levels of accuracy, and the interdisciplinary strengths of having people contributing from other fields. 'I don't want to set ourselves up as heroes... we all have to make compromises and negotiate possibilities,' she says. 'But the key is to use your advantages to collaborate.'

David Poulson, associate director, Knight Center for Environmental Journalism, Michigan State University, posted this comment on 6 December 2010 on Pacific Scoop website: www.pacific.scoop.co.nz

Universities have a special obligation during this period of journalistic upheaval. Much like monasteries preserving literacy during the Dark Ages, universities should be a safe place where professionals as well 
as students can practice credible journalism..... Fine journalism is a public trust entirely consistent with a university's obligation to create and disseminate knowledge and perspective.

Journalists Lynch and McGoldrick (2005) believe that such 'conceptual reforms' are 'necessary to modernise the study of journalism, as taught to journalism students; a contribution to problematising elements of journalistic practice which pass unexamined in many current courses'.

Their course on peace journalism is taught in many universities including Australia, UK and USA as part of peace and conflict studies. It is designed mainly to provide a theoretical understanding of violence, peace and conflict in societies along with media dynamics for the students of journalism, peace studies and international relations.

If there is one real skill in peace journalism it lies in tracing connections between the stories of people.... and the big issues and eye catching events of the day - showing how the actions and concerns of individuals bear indirectly on the personal fortunes of every reader, listener or viewer. To do that journalists need to be able to draw upon a deep understanding of how conflicts develop and how people can respond to them in ways likely to reduce the risk of violence. (Lynch and McGoldrick, 2005)

Hence the course delves deep into Galtung's ideas relating to cultural and structural violence, Noam Chomsky's propaganda model and the role of the media as a social agent for peace.

The model curriculum for journalism education prepared by UNESCO in 2007 is another important initiative. Available at unesdoc.unesco.org/ images/0015/001512/151209E.pdf, these curricula for undergraduate and postgraduate programmes were designed by some of the top journalism educators in the world 'to be adaptable to just about any situation'. The curricula have three categories: professional practice, journalism studies and arts and science. They advance the concept that democracy is based on the free flow of information which represents the full spectrum of the community. These model curricula have been translated into French, Spanish, Arabic, Russian and several other languages and widely distributed among journalism schools in both developing countries and countries in transition. UNESCO has also 
developed a Freedom of Expression Toolkit for secondary school students in post-conflict societies.

A somewhat different initiative which is partly academic in nature is Radio Deutsche Welle's series, Global Media Forum. Inaugurated in 2008, the symposium takes place regularly in Bonn. The main agenda items change but the event always addresses ways to cope with the professionalisation of journalists. At the first forum, with the theme of 'Journalistic training in conflict situations', experts and scholars in journalism were brought together along with media representatives and internationally experienced trainers from all over the world. The forum provided a central platform for those present to share their experiences and discuss the central theme of what qualifications and know-how journalists need in order to contribute to peace and conflict de-escalation. In 2009, the topic was 'Bridging the digital divide-how to prepare your staff'.

\section{Can peace journalism be practised effectively?}

Even though the concept is gaining acceptance and elements of it are being included in journalistic training it is too soon to determine how effective it is. There are many challenges and dangers to be faced. The first is the digital revolution. Several factors affect the training of journalists in the digital world making it a more complicated and complex phenomenon. The digital revolution and advances in satellite technology have given people unprecedented access to global events, with immediate and detailed reporting of war now possible. And while new media technologies do not alter the fundamental tenets of journalism, they do change user behaviour and hence news room paradigms, discussions and decisions. Today, speed and user participation share the same media priorities: authenticity, balance and accuracy.

The disemination of information has also changed to becoming more entertaining, interactive and instantaneous through for instance, blogs, vlogs, SMS and now Twitter. It transcends conventional geographical boundaries and hence has the capacity to absorb audiences at a global level. Therefore, glocalisation (i.e. the ability to view issues from a global perspective while connecting to local sources and understanding the local context) as opposed to globalization would be a critical aspect of any future journalism education. This includes mixing with people of different cultures, living in different countries, learning various languages and understanding local sensitivities. 
The second challenge is more theoretical in nature. Bratic and Schirch (2008) argued that 'the theoretical argument for the media's impact on peace is underdeveloped, the practical projects are vastly scattered and a systematic analysis of the practice is missing'.

\begin{abstract}
A central question in the discussion about those principles revolves around the question of how far journalists should go in advocating peace, but these discussions do little but reiterate old debates about the role of social responsibility model of the press.... While this discussion has its place, its universal and philosophical nature tends to divert and dilute the discussion and it rarely leads toward a broader and more comprehensive understanding of the media. (Bratic \& Schirch, 2008, emphasis added)
\end{abstract}

However, they acknowledge the 'positive media engagement' in conflict prevention and peace-building through entertainment media. And it must be pointed out at this point that many organisations are already working on one or more of these strategies such as:

- $\quad$ documentary competitions (UNESCO, NICR Canada);

- joint television productions (between India and Pakistan by AsiaPacific Institute for Broadcasting Development);

- community radio programmes and dramas (BBC Radio's New Home: New Life in Afghanistan and Pakistan, Oxfam Quebec's Radio Galkayo in Somalia, The New Neighbours in Columbia, and USAID-funded Our Neighbours, Ourselves in Rwanda, Song of Peace in Angola to mention just a few).

The important factor in all these initiatives is that they are pro-active, reconciliatory and designed to counter the 'hate media'.

Other problems related to journalistic training in conflict affected areas include lack of resources, non-availability of local expertise and infrastructure and severe security threats to journalists' lives. For instance, in Iraq all the journalism training is conducted either in the neighboring countries or in Europe because of the daily risk to life which makes such training ventures not only extremely expensive but also condensed in time and content. There is also the danger that a heavy reliance on the foreign expertise further 
pulls the training out of its cultural context.

A unique case in the analysis of journalism training in conflict resolution is the war on terror being fought in Pakistan's tribal areas. These areas lie at the remote end of the North West of Pakistan bordering Afghanistan. Despite being the epicentre of the conflict, there is no access for Pakistani or foreign journalists to cover the conflict. The local journalists not only face death every day but are also looked upon with mistrust by the government and the community. On 16 June 2006, journalist Hayatullah Khan, who was kidnapped by gunmen six months previously, was shot in North Waziristan. A reporter for the English language daily The Nation and the Urdu newspaper, Ausaf, he was also the general secretary of the Tribal Union of Journalists (TUJ) and had been covering the war in Waziristan since the beginning. His family and many others believe he was kidnapped and detained by the security agencies for his reporting on US military action in tribal areas. On the other hand, the local Taliban's approach towards the media is even worse. They are hostile to the presence of any outside media person considering them all 'Western spies'.

Suba Chandran (2006) reported that while the murder of Daniel Pearl (South Asia bureau chief of the Wall Street Journal) in February 2002 attracted much attention and occupied the headlines, the Taliban ban on media in the region had gone largely unnoticed. For instance, two journalists working for the Frontier Post and Khyber TV, Amir Nawab Khan and Allah Noor Wazir, were killed in Wana town by militants in February 2005. Others were luckier: Dilawar Khan Wazir, a Wana-based journalist working with BBC World Service, was warned with a bomb in his compound after he participated in a Voice of America show in December 2005. 'Militants have repeatedly issued threats against any adverse reports, both in the electronic and print media' (Chandran, 2006).

Other media-related NGOs such as Internews Pakistan reported in June 2006 that at least 20 journalists in the tribal areas were killed, kidnapped, arrested, tortured or threatened by the local administration, the law enforcement agencies and Taliban all during the first six months of the conflict. The Pakistan Press Freedom Report (2007) concluded that 'most journalists in tribal areas have either been forced to give up their profession or leave their home town. The few that remain, limit their coverage to innocuous topics such as school functions and activities of administration officers'.

Since then, the only source of information left in these tribal areas is 
provided by the Inter Services Public Relations (ISPR) which is the army's official agency. Its news credibility remains questionable as most of it is written and disseminated not from the conflicted areas but from its offices in Islamabad. ISPR has claimed dozens of Taliban leaders have been killed yet not a single photograph has been released to the press. It has claimed the tribal area of Swat has been cleared of all Taliban elements yet the Radio News Network reported on 21 July 2009 that the Taliban were running an FM radio station-just days after the internally displaced people (IDPs) from the valley were allowed to go back to their homes. (Before the military operation in Swat began in April 2009, an estimated 88 FM radio station were estimated by the local media to be operating illegally in the area, mostly by the Taliban.)

So the problems facing media aiming to promote peace in this situation are vast: when its engagement in the conflict is nil. There is no information available about the human suffering and no images are captured to evoke audience emotions. How can journalists play a positive role in tribal areas such as Waziristan when the community, the Taliban and security forces are violently opposed to their very presence?

The world today is faced with many political, economic and ideological conflicts. There is no denying that the media has been playing a significant role in conflict situations, and, as identified here, there is a wide range of journalistic training projects taking place in the world that aim to develop the media's role in conflict resolution. But there is a great disparity in various parts of the world regarding the media's access to conflict. While the developed world is talking about training journalists in a complex digital world, the simple task of the media gaining access to conflict in war-ridden countries such as Iraq and Pakistan is daunting.

Most of the peace-building initiatives in other parts of the world (such as Colombia, Rwanda and Serbia) started when conflict had crossed its peak point and the local communities were ready to start life anew. This does raise questions regarding the ability of the media to engage in peace-building efforts without any community support as in the tribal areas of Pakistan where none of the three fighting parties - the Taliban, the locals and the security forces - are willing to work with journalists. The support, readiness and will of the people in local communities might very well be the major factor in determining the effectiveness of media's role in conflict resolution and peace building. 


\section{Conclusion}

To conclude, peace journalism is not an end in itself nor is it the ultimate answer to solve the plights of contemporary journalism. The value of peace journalism lies in the possibility of it bringing a positive change in the media's coverage of conflict situations and a better understanding to the people as to why do they happen. The current trend shows that the concept has gained greater acceptance among the academicians and journalists across the world and there is a paradigm shift of the traditional media approach towards conflict. The ideals of peace journalism do not fundamentally change journalistic good practice and as an approach, it has the flexibility to encompass other forms of media. The examples discussed above show it is being practised in many forms in several countries, even though they are scattered. There is hope for it to grow. Journalists, academics, and conflict resolution experts have to embrace it in their minds, make it applicable within their own domains and then promote it as a plausible solution to others. The special Peace Journalism Forum at Auckland University of Technology was among such initial efforts. Hopefully, there will be many more.

\section{References}

Adam, G. \& Holguin, L. (2003). The media's role in peace building: Asset or liability? Paper presented to the Media 3 conference, Barranquilla, Colombia

Allan, S. (2007). Citizen journalism and the rise of 'mass-self communication': Reporting the London bombings, Global Media Journal, Australian edition, 1(1). Retrieved on 17 June 2009, from stc.uws.edu.au/gmjau/iss1_2007/pdf/HC_FINAL_Stuart\%20Allan.pdf

Aslam, $\bar{R}$. (2010). Perspectives on conflict resolution and journalistic training. In Keeble et al (Eds.), Peace journalism, war and conflict resolution. London: UK: Peter Lang

Bacon, W. (2010). What role for the University in the future of investigative journalism? Keynote speech at the Media, Investigative Journalism and Technology (MIJT) Conference, AUT University, Auckland, Retrieved on 4 December 2010, from pacific.scoop.co.nz/2010/12/mijt-conference-journalist-educator-callsacademia-to-collaborate/

Barnes, R. (2010). Twittering the News: A case for realigning journalism education. Paper presented at the Media, Investigative Journalism and Technology (MIJT10) conference, AUT University, Auckland, 4-5 December 2010.

Bell, M. (1998). The journalism of attachment. In Kieran, M. (Ed.) Media ethics (pp. 15-22). London: Routledge.

Botes, J. (2000). Regional media in conflict. Paper presented at the Institute for War and Peace Reporting, London. 
Bratic, V. \& Schirch, L. (2008). The role of media in peace building: Theory and practice. Paper presented at the symposium on journalistic training in conflict relation situations. Bonn: DW-AKADEMIE. Retrieved on 21 July 2009, from www.kubatana.net/docs/media/dw_journalistsic_training_symposium_2008.pdf

Brosius, H. \& Weimann, G. (1996). Who sets the agenda? Agenda-setting as a twostep flow, Communication Research, 23(5), pp. 561-580

Chandran, S. (2006). Waziristan: Taliban, state and media, Institute of Peace and Conflict Studies, Retrieved on 20 December 2010, from www.ipcs.org/articledetails.php? articleNo=2048

Chattarji, S. (2006). Negative reportage in Indo-Pak media. Retrieved online on 27 March 2007. www.thehoot.org/web/home/story.php?storyid=1985\&pg=1\&mo $\mathrm{d}=1 \&$ sectionId $=38 \&$ sectionname $=I N D O \% 20 \mathrm{PAK} \% 20$ MONITORING\&valid=true

Devere, H. (2010). Peace Journalism: a goal or a dream? Paper presented at the Media, Investigative Journalism and Technology (MIJT10) conference, AUT University, Auckland, 4-5 December 2010.

Dietz, B. (2006). The last story: Hayatullah Khan, Committee to Protest Journalists. Retrieved on 1 May 2009, fromn http://cpj.org/reports/2006/09/khan.php

Dixit, K. (2011). Real investigative journalism in a virtual world. Pacific Journalism Review, 17(1), pp. 10-18.

Entman, R.M. (1993). Framing: Toward clarification of a fractured paradigm, Journal of Communication, 43(4), pp. 51-8.

Galtung, J. (1998). High Road, Low Road - Charting the Road for Peace Journalism, Track Two, 7(4).

Hager, N. (2010). More investigation when there is less journalism. Keynote speech at the Media, Investigative Journalism and Technology (MIJT10) conference at AUT University, Auckland, 5 December 2010. Retrieved on 20 December 2010, from http://pacific.scoop.co.nz/2010/12/mijt-conference-nicky-hager-proposesreconceptualisation-of-investigative-journalism/

Hawkins, K. (2010). Investigative journalism: Something from nothing. Paper presented at the Media, Investigative Journalism and Technology (MIJT10) conference, AUT University, Auckland, 4-5 December 2010. Retrieved on 20 December 2010, from www.pmc.aut.ac.nz/content/mijt-2010-conference-papers-and-proceedings

Howard, R. (2003). The media's role in war and peace building. Presented to conference on the role of media in public scrutiny and democratic oversight of the security sector, Budapest.

Internews, Pakistan. (2006). Half yearly report on attacks on media. Retrieved on 20 December 2010, from www.internews.org.pk/HalfYearly\%20reportabout\%20 attackson $\% 20$ media.doc

Lederach, John P. (1997). Building peace-sustainable reconciliation in divided societies. Washington: United States Institute of Peace Press.

Loyn, D. (2007). Good journalism or Peace journalism?; Conflict \& Communication online, 6(2). Retrieved from www.cco.regener-online.de

Lynch, J. \& McGoldrick, A. (2001). Reporting the world. London: Conflict and Peace Forum. 
Lynch, J. \& McGoldrick, A. (2005). Peace journalism. Stroud: Hawthorn Press.

Lynch, J. (2008). Debates in peace journalism. Sydney: Sydney University Press. Mottaghi, J. (2008). Media diversity: Training for a digital world. Paper presented at a symposium on journalistic training in conflict situations, Bonn: Retrieved on 21 July 2010, from www.kubatana.net/docs/media/dw_journalistsic_training_symposium 2008.pdf

Pakistan Press Foundation. (2007). Pakistan press freedom report. Retrieved on 23 July 2009, from www.pakistanpressfoundation.org/userRAndDDetails.asp?uid=248

Robie, D. (2011). Conflict reporting in the South Pacific: Why peace journalism has a chance. Journal of Pacific Studies (forthcoming).

Schubart, R. (2009). War isn't hell, its entertainment: Essays on visual media and the representation of conflict. In Virchow, F., White-Stanley, D., and Thomas. Jefferson, North Carolina: McFarland \& Company.

Singh, S. (2010). Fiji needs free media that is also 'social responsible'. Paper presented at the Media, Investigative Journalism and Technology (MIJT10) conference at AUT University, Auckland, 5 December 2010. Retrieved on 20 December 2010, from www.pmc.aut.ac.nz/content/mijt-2010-conference-papers-and-proceedings Stephenson J. (2010). How the war was spun: the media, the NZ Defence Force and Afghanistan. Presented at the Media, Investigative Journalism and Technology (MIJT10) conference, AUT University, Auckland, 4-5 December 2010.

Verbitsky, J. (2010). Links between conflict resolution and peace journalism. Paper presented at the Media, Investigative Journalism and Technology (MIJT10) conference, AUT University, Auckland, 4-5 December 2010.

Waqa, M. (2010). How peace journalism surfaced in the Pacific? 15 December 2010. Letter to the Café Pacific blog: Retrieved on 20 December 2010, from cafepacific. blogspot.com/2010/12/how-peace-journalism-surfaced-in.html

Rukhsana Aslam, a Masters graduate from City University in Britain, is a journalist and journalism educator from Pakistan. With more than a decade in the mainstream media and eight years in higher education, she was most recently chair at the Centre for Media and Communication Studies, International Islamic University, Women's Campus, Islamabad. Aslam contributed a chapter on peace journalism in Peace Journalism, War and Conflict Resolution (Keeble, Tulloch and Zollman, New York: Peter Lang, 2010). She is currently engaged in doctoral peace journalism research at AUT University in New Zealand, where she is attached to the Pacific Media Centre. She was a convenor of the Peace Journalism Forum at the Media, Investigative Journalism and Technology (MIJT10) conference at AUT University on 4-5 December 2010.

rukhsanaaslamkhan@hotmail.com 